\title{
Pharmacokinetics of treprostinil in children with functional single-ventricle pulmonary arterial hypertension: a randomized controlled trial
}

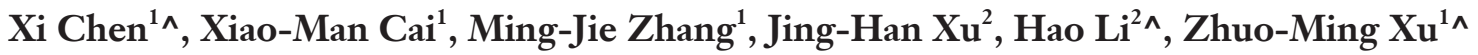 \\ ${ }^{1}$ Department of Thoracic and Cardiovascular Surgery, Shanghai Children's Medical Center, School of Medicine, Shanghai Jiao Tong University, \\ Shanghai, China; ${ }^{2}$ Department of Pharmacy, Clinical Research Center, Shanghai Children's Medical Center, School of Medicine, Shanghai Jiao Tong \\ University, Shanghai, China \\ Contributions: (I) Conception and design: ZM Xu; (II) Administrative support: ZM Xu; (III) Provision of study materials or patients: XM Cai; (IV) \\ Collection and assembly of data: X Chen, JH Xu, MJ Zhang; (V) Data analysis and interpretation: X Chen, H Li; (VI) Manuscript writing: All \\ authors; (VII) Final approval of manuscript: All authors. \\ Correspondence to: Hao Li. Department of Pharmacy, Clinical Research Center, Shanghai Children's Medical Center, School of Medicine, Shanghai \\ Jiao Tong University, No. 1678 Dongfang Road, Shanghai 200127, China. Email: lihao19880810@hotmail.com; Zhuo-Ming Xu. Department of \\ Thoracic and Cardiovascular Surgery, Shanghai Children's Medical Center, School of Medicine, Shanghai Jiao Tong University, No. 1678 Dongfang \\ Road, Shanghai 200127, China. Email: zmxcicu@163.com.
}

Background: Application of Treprostinil (TRE) in the patients with single ventricle (SV) physiology is very limited, and the optimal dose for children has not been determined. In this study, we aimed to analyze plasma samples to assess the attainment of clinically therapeutic concentrations of TRE and its efficacy and safety in the treatment of pediatric functional SV pulmonary arterial hypertension (FSV-PAH)..

Methods: Pediatric patients with FSV-PAH were recruited in this study. IV TRE at an initial rate of $5 \mathrm{ng} / \mathrm{kg} / \mathrm{min}$ was administered through the femoral vein with an increase in rate to $10 \mathrm{ng} / \mathrm{kg} / \mathrm{min}$ every $30 \mathrm{~min}$ until the aiming dose of $80 \mathrm{ng} / \mathrm{kg} / \mathrm{min}$ had been reached. The drug was gradually discontinued after $12 \mathrm{~h}$ of treatment at a stable dose. The mean postoperative pulmonary artery pressure (mPAP), pulmonary-tosystemic arterial pressure ratio $(\mathrm{Pp} / \mathrm{Ps})$, and the ratio between arterial oxygen partial pressure and inhaled oxygen concentration $\left(\mathrm{PaO}_{2} / \mathrm{FiO}_{2}\right)$ were used to evaluate the efficacy of TRE treatment. A multiple linear regression model was used to explore the relevant factors associated with TRE blood concentration.

Results: A total of eight patients were enrolled in the investigation, with an age range of 2.5-9.9 years. The median stable dose of TRE was $70 \mathrm{ng} / \mathrm{kg} / \mathrm{min}$ with a range of $55-75 \mathrm{ng} / \mathrm{kg} / \mathrm{min}$. The median subliminal dose was $55 \mathrm{ng} / \mathrm{kg} / \mathrm{min}$ with a range of $25-75 \mathrm{ng} / \mathrm{kg} / \mathrm{min}$. A linear relationship was established between the TRE dose and the plasma concentration. TRE blood concentrations were associated with dose and patient height. After TRE treatment, mPAP, $\mathrm{Pp} / \mathrm{Ps}$, and $\mathrm{PaO}_{2} / \mathrm{FiO}_{2}$ were significantly improved $(\mathrm{P}<0.05)$.

Conclusions: A linear relationship was found between the blood concentration of TRE and its dose. IV TRE was an effective therapy without serious side effects in pediatric patients with FSV-PAH.

Trial Registration: ClinicalTrials.gov Identifier: NCT02865733.

Keywords: Single ventricle; pulmonary hypertension; treprostinil; pharmacokinetics

Submitted May 18, 2021. Accepted for publication Jul 14, 2021.

doi: 10.21037/atm-21-3188

View this article at: https://dx.doi.org/10.21037/atm-21-3188

^ ORCID: Xi Chen, 0000-0001-6440-4221; Hao Li, 0000-0003-2832-4851; Zhuo-Ming Xu, 0000-0001-5695-8662. 


\section{Introduction}

Congenital heart disease (CHD) is one of the most common types of major congenital malformations and is the leading cause of mortality from birth defects (1). According to ESC 2020, the prevalence of CHD worldwide is $\sim 9$ per 1,000 newborns, with substantial geographic variation (2). Single ventricle (SV) CHD is a severe cardiac malformation associated with left or right ventricle underdevelopment, resulting in a single functional ventricular chamber that supplies both the systemic and pulmonary circulations (3). It accounts for up to $3 \%$ of all cases of CHD (4). The key determinants of single-ventricle physiology include pulmonary vascular resistance (PVR) and systemic ventricular function $(5,6)$. PVR is considered the main determinant affecting the driving force of the ventricular preload, especially in patients with apparently good ventricular and valve function. Increased PVR leads to functional SV pulmonary arterial hypertension (FSV-PAH) (7). According to the latest ESC guidelines, FSV-PAH falls within group 1 of the PAH classification and needs PAH-directed medical therapy (2). Optimizing PVR from the outset is critical due to its unique physiological cycles. Patients with SV physiology who do not fulfill the classic criteria for PAH (mean pulmonary artery pressure (PAP) $>25 \mathrm{mmHg}$ and PVR index $>3$ ) were found to be amenable to pulmonary vasodilator therapy (4). Based on the information above, there seems to be a rationale for pulmonary vasodilator therapy in FSV-PAH. However, only scarce clinical evidence exists to guide its application, especially in the early postoperative stage (8). In general, there is no approach currently available to administer oral pulmonary vasodilation in the early postoperative period after Fontan completion. Inhaled nitric oxide (iNO) is mainly used in the ICU and is helpful for patients with acute pulmonary vascular crisis or acute exacerbations of PAH, such as underlying parenchymal lung disease or persistent pulmonary hypertension in the newborn (9). Nevertheless, our previous study on the therapeutic application of iNO in the treatment of FSV-PAH showed that a pulmonary arterial pressure bounce might occur after the withdrawal of iNO (10). More importantly, the recommended ESC guidelines state that the application of iNO has to be supplemented by ventilation, which contradicts the principle of early extubation after Fontan surgery. Thus, a pressing demand exists for intravenous preparations for the treatment of FSV-PAH.

Treprostinil (TRE) is a synthetic analog of prostacyclin approved for the treatment of Group 1 or PAH. It is a direct vasodilator of both pulmonary and systemic vascular beds, thereby reducing pulmonary artery pressure and improving systemic oxygenation $(11,12)$. According to 2019 updated consensus statement on the diagnosis and treatment of pediatric pulmonary hypertension, in severe and/or rapidly progressive $\mathrm{PAH}$, continuous IV epoprostenol or treprostinil therapy should be started without delay (9). Recently, some reports about the TRE in children evaluated the pharmacokinetics (PK) of intravenous (IV) and subcutaneous (SC) TRE in pediatric patients with pulmonary vascular disease $(13,14)$. However, the optimal dose for children has not been determined. In addition, due to the unique physiological mechanism of Fontan circulation, there is no convincing evidence for the efficacy of TRE application. Therefore, in this study, we aimed to analyze plasma samples to assess the attainment of clinically therapeutic concentrations of TRE and its efficacy and safety in the treatment of pediatric FSV-PAH.

We present the following article in accordance with the CONSORT reporting checklist (available at https://dx.doi. org/10.21037/atm-21-3188).

\section{Methods}

\section{Trial design and study population}

The study population was derived from a randomized, parallel, single-blind clinical study registered in ClinicalTrials.gov (NCT02865733). Patients were randomly assigned in a 1:1 ratio receive therapy. In this study, subjects were blinded to during the trial. The following inclusion criteria were applied: (I) patients had FSV and were undergoing the Fontan operation in National Children's Medical Center (Shanghai Children's Medical Center); (II) they had a mean pulmonary arterial pressure (mPAP) greater than $15 \mathrm{mmHg}$; (III) a transpulmonary pressure (TPG) greater than $6 \mathrm{mmHg}$; and (IV) their legal guardians agreed to their participation in the study and signed the informed consent form. The exclusion criteria were as follows: (I) severe arrhythmia leading to a low cardiac output syndrome; (II) a platelet count $<50,000 \times 10^{9} / \mathrm{L}$ and obvious bleeding.

\section{Ethical approval}

This study was approved by the Ethics Committee of Shanghai Children's Medical Center affiliated with Shanghai 
Jiao Tong University School of Medicine (approval number: SCMCIRB-K201538). The protocol was conducted in accordance with good clinical practice and the Helsinki Declaration (as revised in 2013). After receiving oral and written explanations of the study, the subjects' legal guardians gave written informed consent before starting the study.

\section{Intervention}

Patients were intravenously administered TRE at an initial rate of $5 \mathrm{ng} / \mathrm{kg} / \mathrm{min}$ through the femoral vein, increasing to $10 \mathrm{ng} / \mathrm{kg} / \mathrm{min}$ every $30 \mathrm{~min}$ until $80 \mathrm{ng} / \mathrm{kg} / \mathrm{min}$ was reached. Finally, the drug was gradually discontinued after $12 \mathrm{~h}$ of treatment at a stable dose. The primary outcome is TRE effects, including pulmonary-to-systemic vascular pressure ratio $(\mathrm{Pp} / \mathrm{Ps})$, mean postoperative pulmonary arterial pressure (mPAP) and the oxygenation index $\left(\mathrm{PaO}_{2} /\right.$ $\mathrm{FiO}_{2}$ ). We defined the subliminal dose as the dosage when $\mathrm{Pp} / \mathrm{Ps}$ decreased by $10 \%$, and a stable dose as the dose at which the nadir occurred. The hemodynamic indicators of all patients were monitored to obtain $\mathrm{mPAP}$ and $\mathrm{Pp} / \mathrm{Ps}$. In addition, $\mathrm{PaO}_{2} / \mathrm{FiO}_{2}$ and the positive inotropic drug score (IS) were calculated.

The following formula was used to calculate the dilution concentration of TRE:

Dilution concentration $(\mathrm{mg} / \mathrm{mL})=\frac{\text { Dose }(\mathrm{ng} / \mathrm{kg} / \mathrm{min}) * 0.00006}{\text { Intraveous } \inf \text { usion rate }(\mathrm{mL} / \mathrm{h})}$

\section{Blood sample collection and analysis}

Blood samples were drawn from an intravenous cannula at the following time points: $0,0.5,1.0,1.5,2.0,2.5,3.0,3.5$, 4.0, and $16.5 \mathrm{~h}$, and at 2 and $4 \mathrm{~h}$ after TRE withdrawal. At each time point, approximately $2 \mathrm{~mL}$ of blood was collected from each subject into K3-EDTA tubes and centrifuged at $4{ }^{\circ} \mathrm{C}$ for $15 \mathrm{~min}$ at $3,000 \times \mathrm{g}(15)$. Then, $1 \mathrm{~mL}$ of frozen plasma was shipped on solid carbon dioxide (Drikold) to an analytical laboratory (Pharmaceutical Molecular Laboratory, Fudan University, Shanghai, China). An Api3000 Mass Spectrometer (Applied Biosystems, Foster City, CAUSA), an ANASTAR analyst (version 1.4.1, Applied Biosystems, USA), and an HP 1100 high-performance liquid chromatograph (Agilent Technologies, Palo Alto, CA, USA) were used in the analyses. TRE concentrations were measured using a liquid chromatography-tandem mass spectrometry (LC-MS/MS).

\section{Statistical analyses}

The results are expressed as mean \pm standard deviations or interquartile range. Correlation analysis was used to assess the relationship between dose and concentration. A multiple linear regression analysis with a stepwise approach was used to examine the association of demographic, dose, and clinical data with TRE blood concentrations. TRE blood concentration was taken as the dependent variable, and background factors (age, height, body surface area), peritoneal dialysis data, hepatic, and renal functions were taken as the independent variables. A stepwise method was used where a variable was entered into the model if the significance level of its $\mathrm{F}$ value was less than 0.05 and removed if the significance level was greater than 0.10 . A coefficient of determination $\left(\mathrm{R}^{2}\right)$ was calculated, which measures how well a model fits the data. Paired $t$-tests were employed to compare the pre- and post-treatment efficacy. Statistical significance was set at $\mathrm{P}<0.05$.

\section{Results}

\section{Patient characteristics}

A total of 40 patients were recruited from the National Children's Medical Center (Shanghai Children's Medical Center) between August 2016 and August 2019. Thirtysix patients were randomized. Twelve agreed to undergo PK monitoring, including eight in the intervention group and four in the control group (Figure 1). The PK test was completed in eight patients (six males and two females). Patient characteristics are shown in Table 1. The main laboratory test results pre- and post-TRE treatment are shown in Table 2.

\section{Treprostinil concentrations}

The PK of TRE appeared to be approximately linear in the dose range $5-80 \mathrm{ng} / \mathrm{kg} / \mathrm{min}$, and the corresponding blood concentration was about $0.05-21.7 \mathrm{ng} / \mathrm{mL}$ (Figure 2). Based on the $\mathrm{Pp} / \mathrm{Ps}$ values, the subliminal dose range was $25-75 \mathrm{ng} / \mathrm{kg} / \mathrm{min}$, and the average dose was $52.5 \pm 16.69 \mathrm{ng} / \mathrm{kg} / \mathrm{min}$. The stable dose range of patients was $55-75 \mathrm{ng} / \mathrm{kg} / \mathrm{min}$ with an average dose of $65.00 \pm 7.07 \mathrm{ng} / \mathrm{kg} / \mathrm{min}$. In the corresponding blood conc/min, the drug concentration was $1.1-22.6 \mathrm{ng} / \mathrm{mL}$ after $12 \mathrm{~h}$ (Table 3).

Moreover, the drug concentration was determined within the range $0.32-13.5 \mathrm{ng} / \mathrm{mL}$ after $2 \mathrm{~h}$ of drug withdrawal 


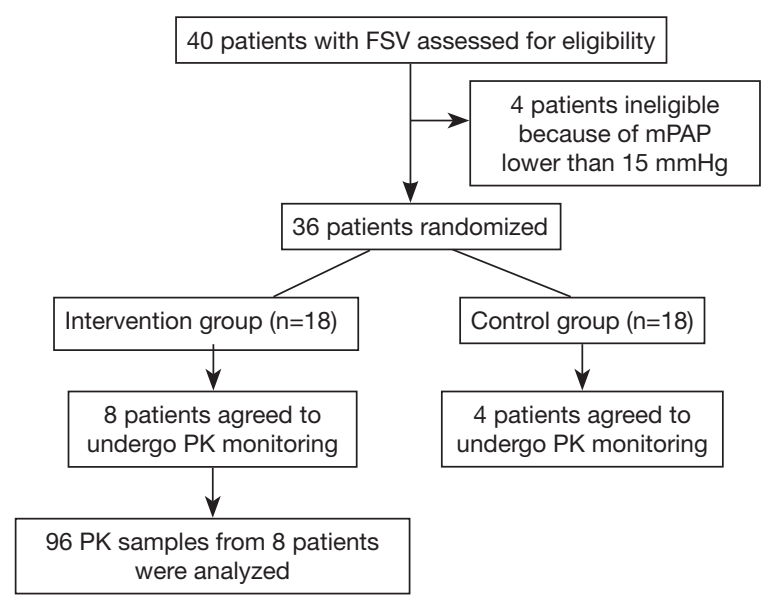

Figure 1 Study profile. FSV, function single ventricle; PK, pharmacokinetics. and $0.08-4.66 \mathrm{ng} / \mathrm{mL}$ after $4 \mathrm{~h}$ of drug withdrawal (Table 3). The mean plasma concentration-time curves after the application of single doses are presented in Figure 3. Results from the multiple linear regression model indicated that TRE blood concentration was associated with dose and height (adjusted $\mathrm{R}^{2}=0.802 ; \mathrm{P}<0.001$ ) (Table 4). These two factors appear to explain $80.2 \%$ of the observed variance in concentration.

\section{Therapeutic effects}

The duration of continuous medication ranged from 22.5 to $48.5 \mathrm{~h}$, and the mean duration of medication was $40.18 \pm 8 \mathrm{~h}$. Of note, $4 \mathrm{~h}$ after drug withdrawal, mPAP $(15.38 \pm 3.5 \mathrm{vs}$. $18.63 \pm 3.66, \mathrm{P}=0.021)$ and $\mathrm{Pp} / \mathrm{Ps}(0.22 \pm 0.06$ vs. $0.35 \pm 0.11$,

Table 1 Demographic information

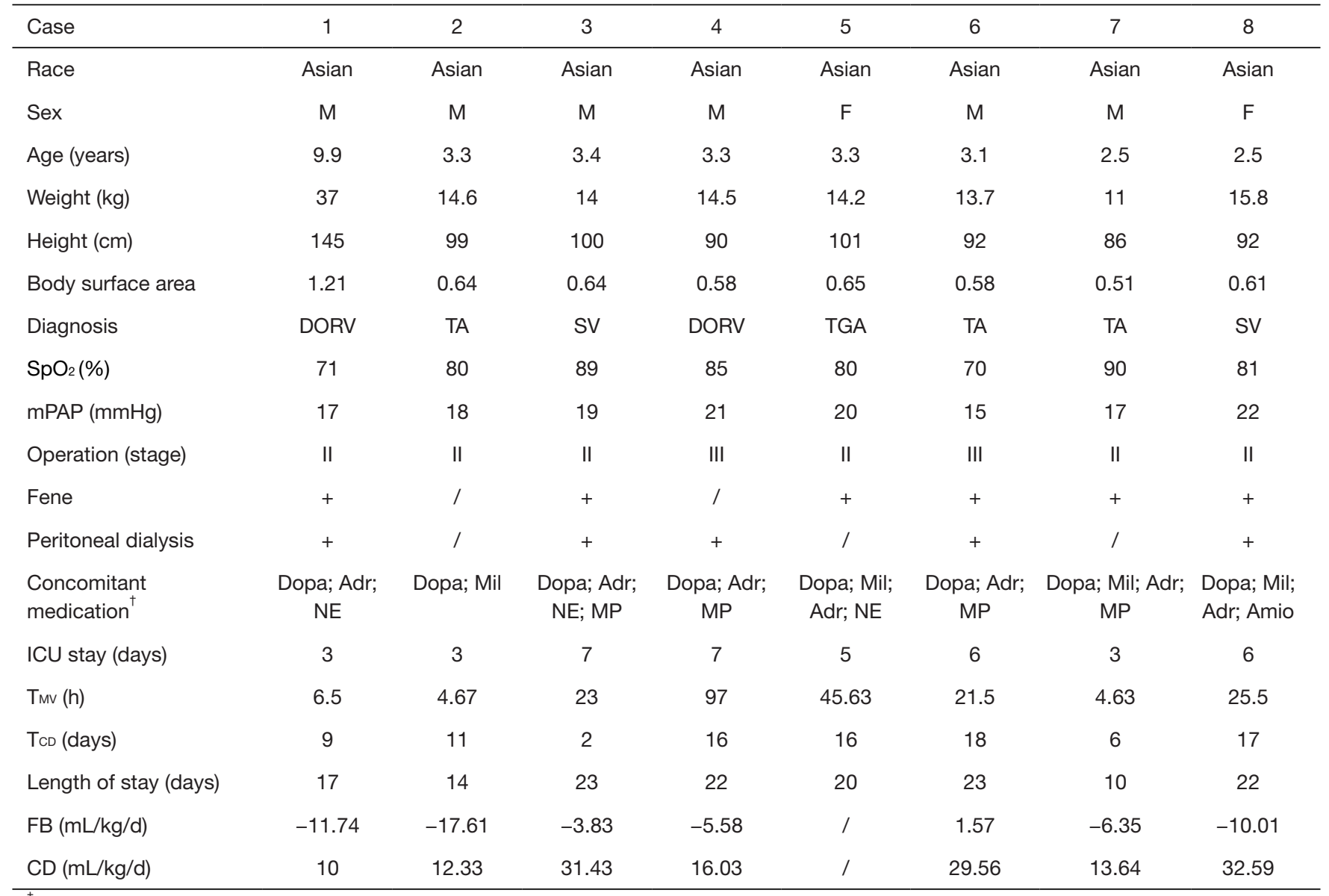

${ }^{\dagger}$, concomitant medication during intravenous infusion of treprostinil; +, yes. mPAP, mean pulmonary artery pressure; Fene, fenestration; ICU, intensive care unit; DORV, double outlet right ventricle; TA, tricuspid atresia; SV, single ventricle; TGA, transposition of great arteries; $\mathrm{T}_{\mathrm{Mv}}$, mechanical ventilation time; TcD, chest drainage time; FB, fluid balance; CD, chest drainage; Dopa, dopamine; Mil, milrinone; Adr, adrenergic; NE, noradrenaline; ISO, isoproterenol; MP, methylprednisolone; Amio, amiodaron. 
Table 2 Main laboratory test results before and after intravenous infusion of treprostinil

\begin{tabular}{|c|c|c|c|c|c|c|c|c|}
\hline Case & 1 & 2 & 3 & 4 & 5 & 6 & 7 & 8 \\
\hline WBC $\left(\times 10^{9} /\right.$ L) $[4.0-15.0]$ & 4.1 & 6.4 & 8.3 & 17.2 & 6.3 & 6.4 & 9.3 & 9.9 \\
\hline $\operatorname{RBC}\left(\times 10^{12} / L\right)[3.7-5.8]$ & $7.1 \uparrow$ & $5.91 \uparrow$ & 5.2 & $6.14 \uparrow$ & 5.66 & 5.7 & 5.43 & 5.2 \\
\hline $\mathrm{HB}(\mathrm{g} / \mathrm{L})$ [110-160] & $219 \uparrow$ & $175 \uparrow$ & 149 & $179 \uparrow$ & 160 & $169 \uparrow$ & 151 & 158 \\
\hline L\% [20-40] & 29.8 & 37.4 & 37.2 & 20.2 & 35.9 & $46.1 \uparrow$ & $48.4 \uparrow$ & $69.1 \uparrow$ \\
\hline PLT $\left(\times 10^{9} / L\right)[100--550]$ & 241 & 222 & 439 & 132 & / & 357 & 349 & 356 \\
\hline CREA ( $\mu \mathrm{mol} / \mathrm{L})$ [9-88] & 42 & 35 & 56 & 11 & / & 27 & 31 & 35 \\
\hline AST (U/L) [15-46] & 29 & 24 & 34 & 32 & / & 41 & 35 & 32 \\
\hline NT-proBNP (pg/mL) [0-125] & 6 & 14 & 66 & 23 & / & $349 \uparrow$ & 35 & 30 \\
\hline ROSS Class & 1 & I & I & I & 1 & 1 & 1 & I \\
\hline \multicolumn{9}{|l|}{ Echo } \\
\hline Common atrioventricular regurgitation & + to ++ & - & + & - & - & - & - & - \\
\hline Anastomotic obstruction & - & - & - & - & - & - & - & - \\
\hline$\Delta \mathrm{P}(\mathrm{mmHg})$ & / & / & / & / & / & / & 58 & / \\
\hline \multicolumn{9}{|l|}{ After treatment [normal range] } \\
\hline WBC $\left(\times 10^{9} / L\right)[4.0-15.0]$ & $15.4 \uparrow$ & 8.7 & $18.1 \uparrow$ & $15.2 \uparrow$ & $15.9 \uparrow$ & $15.8 \uparrow$ & 14.4 & 12.5 \\
\hline CREA ( $\mu \mathrm{mol} / \mathrm{L})$ [9-88] & / & / & 52 & / & 41 & 48 & 27 & 42 \\
\hline AST (U/L) [15-46] & / & / & $50 \uparrow$ & / & $68 \uparrow$ & 30 & $84 \uparrow$ & $456 \uparrow$ \\
\hline ALT (U/L) [13-69] & / & / & 11 & / & 31 & 7 & 15 & $638 \uparrow$ \\
\hline $\mathrm{CRP}(\mathrm{mg} / \mathrm{L})[<8]$ & / & $50 \uparrow$ & $20 \uparrow$ & $82 \uparrow$ & $65 \uparrow$ & $10 \uparrow$ & $69 \uparrow$ & $11 \uparrow$ \\
\hline PCT $(\mathrm{ng} / \mathrm{mL})[<0.5]$ & / & / & $3.53 \uparrow$ & $1.4 \uparrow$ & $1.24 \uparrow$ & $7.94 \uparrow$ & $8.95 \uparrow$ & $5.62 \uparrow$ \\
\hline NT-proBNP (pg/mL) [0-125] & $240 \uparrow$ & / & / & / & $3,700 \uparrow$ & $4,000 \uparrow$ & / & $1,100 \uparrow$ \\
\hline $\mathrm{SaO}_{2}-\mathrm{SvO}_{2}(\%)$ & / & 14.9 & 45.8 & 20.9 & 34.1 & 27.5 & / & 48.6 \\
\hline $\mathrm{PvCO}_{2}-\mathrm{PaCO}_{2}(\mathrm{mmHg})$ & / & 3.1 & 13.8 & 10.7 & 6.5 & 6.1 & / & 12.9 \\
\hline $\mathrm{Lac}(\mathrm{mmol} / \mathrm{L})$ & 0.9 & 1.1 & 1.1 & 1.1 & 1.4 & 1.3 & 0.6 & 1.2 \\
\hline
\end{tabular}

Table 2 (continued) 
Table 2 (continued)

\begin{tabular}{|c|c|c|c|c|c|c|c|c|}
\hline Case & 1 & 2 & 3 & 4 & 5 & 6 & 7 & 8 \\
\hline \multicolumn{9}{|c|}{ Before discharge [normal range] } \\
\hline WBC $\left(\times 10^{9} / L\right)[4.0-15.0]$ & 7.8 & 10.4 & 10.3 & 8.2 & 13 & 10.9 & $15.7 \uparrow$ & $17.1 \uparrow$ \\
\hline $\mathrm{RBC}\left(\times 10^{12} / \mathrm{L}\right)[3.7-5.8]$ & 4.87 & 4.69 & 3.78 & 5.23 & 4.16 & 4.35 & 5.55 & 4.17 \\
\hline $\mathrm{HB}(\mathrm{g} / \mathrm{L})$ [110-160] & 154 & 137 & 111 & 152 & 120 & 131 & 158 & 123 \\
\hline L\% [20-40] & $15.6 \downarrow$ & 27.5 & 22.4 & 27.6 & $18.9 \downarrow$ & 33.2 & 23.1 & 34.5 \\
\hline PLT $\left(\times 10^{9} / \mathrm{L}\right)$ [100-550] & 116 & 198 & $650 \uparrow$ & 258 & 420 & 178 & 236 & 401 \\
\hline CREA ( $\mu \mathrm{mol} / \mathrm{L})$ [9-88] & 45 & / & / & / & 18 & / & 39 & 32 \\
\hline AST (U/L) [15-46] & 27 & / & / & / & 36 & / & 34 & 19 \\
\hline
\end{tabular}

Common atrioventricular regurgitation: '+' means mild regurgitation; '++' means moderate regurgitation; '-' means no regurgitation. Anastomose: '-' means patent; '+' means obstruction. WBC, white blood cell count; RBC, red blood cell count; HB, hemoglobin; N\%, percentage of neutrophils; L\%, percentage of lymphocytes; PLT, platelet; CREA, creatinine; AST, aspertate aminotransferase; ALT, alanine aminotransferase; CRP, C-reactive protein; PCT, procalcitonin; NT-proBNP, N-terminal pro brain natriuretic peptide; SaOz, arterial oxygen saturation; $\mathrm{SvO}_{2}$, venous oxygen saturation; $\mathrm{PvCO}_{2}$, venous partial carbon dioxide pressure; $\mathrm{PaCO}_{2}$, arterial partial carbon dioxide pressure; Lac, lactic acid.

$\mathrm{P}=0.002)$ were lower than the baseline values before the treatment, whereas a significant improvement was observed in $\mathrm{PaO}_{2} / \mathrm{FiO}_{2}(162.29 \pm 56.16$ vs. $102.57 \pm 34.3, \mathrm{P}=0.028)$. IS scores did not change (Table 5). The days of ICU stay were $5.00 \pm 1.41 \mathrm{~d}$, the mechanical ventilation time was 21 $[4,27] \mathrm{h}$, the chest drainage time was $11.88 \pm 5.84 \mathrm{~d}$, and the hospital stay was $18.88 \pm 4.79 \mathrm{~d}$.

\section{Adverse effects}

No pain or reactions (erythema, sclerosis, or rash) were observed at the infusion site in any of the eight patients. A decrease in platelet count after TRE treatment was observed in all patients. However, the platelet count recovered before discharge in the absence of a platelet transfusion. Therefore, the decrease in platelets was considered to be surgery related. Abnormal increases of AST and ALT were observed in one patient. No serious adverse side effects occurred, including phlebitis, diarrhea, edema, or nausea.

\section{Discussion}

TRE was used either as a second-line therapy, added to a phosphodiesterase-5 inhibitor (sildenafil) or an endothelin receptor antagonist (bosentan), or as a third-line therapy, added to a biotherapy with sildenafil and bosentan. Overall, 12 clinical trials on treprostinil for children with $\mathrm{PH}$ were registered on the clinical trial registries from the World Health Organization network (16). According to previous reports, TRE therapy is safe and efficacious in pediatric CHD patients with PAH (17-19). Intravenous (IV) or subcutaneous (SC) administration are two available options for continuous TRE use (13). However, both routes have some limitations. TRE IV administration occurs via a central line catheter, but this can be complicated by infection or occlusion. SC administration via a SC catheter can be complicated by pain at the SC infusion site (20). A pharmacokinetics study compared the differences between IV and SC TRE in pediatric patients with pulmonary vascular disease (13). Although blood concentrations per given dose of IV TRE were higher than those per given dose of SC TRE, the difference was not significant (13). As our pediatric patients with FSV-PAH were in a cardiac surgery intensive care unit, we gave priority to IV administration of TRE via a central venous catheter under the best nursing conditions. But to avoid risks such as sepsis and thrombosis caused by long-term TRE administration through a central venous line, SC infusion, or an inhalation 

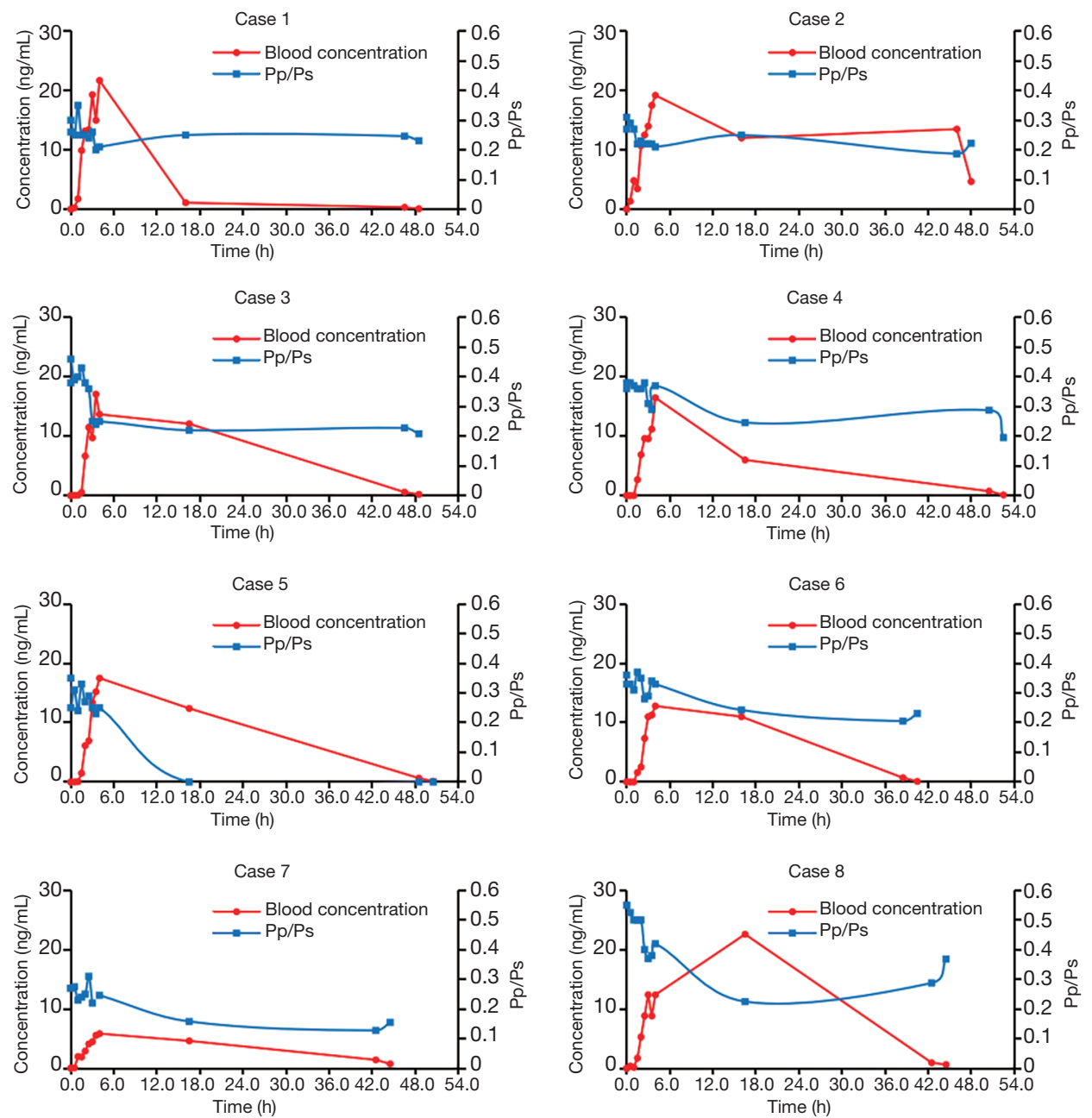

Figure 2 Variation tendency of treprostinil concentration and $\mathrm{Pp} / \mathrm{Ps}$, the ratio of the pulmonary arterial pressure to the systemic pressure.

Table 3 Treprostinil concentrations

\begin{tabular}{lllllllll}
\hline Case & 1 & 2 & 3 & 4 & 5 & 6 & 7 & 8 \\
\hline$D_{\text {sm }}(\mathrm{ng} / \mathrm{kg} / \mathrm{min})$ & 75 & 25 & 65 & 65 & 45 & 55 & 65 & 55 \\
$\mathrm{C}_{\mathrm{Dm}}(\mathrm{ng} / \mathrm{mL})$ & 21.70 & 19.20 & 13.70 & 16.50 & 17.50 & 12.80 & 5.85 & 12.40 \\
$\mathrm{Pp} / \mathrm{Ps}-\mathrm{Dm}$ & 0.21 & 0.21 & 0.25 & 0.37 & 0.27 & 0.24 & 0.25 & 0.42 \\
$\mathrm{D}_{\mathrm{s}}(\mathrm{ng} / \mathrm{kg} / \mathrm{min})$ & 70 & 70 & 65 & 75 & 65 & 55 & 65 & 55 \\
$\mathrm{C}_{\mathrm{s}}(\mathrm{ng} / \mathrm{mL})$ & 1.10 & 12.00 & 12.10 & 6.01 & 12.40 & 11.00 & 4.63 & 22.6 \\
$\mathrm{Pp}_{\mathrm{Ps}}$ & 0.25 & 0.25 & 0.22 & 0.25 & - & 0.24 & 0.16 & 0.23 \\
$\mathrm{C}_{\mathrm{w}-2 \mathrm{~s}}(\mathrm{ng} / \mathrm{mL})$ & 0.32 & 13.50 & 0.58 & 0.74 & 0.65 & 0.71 & 1.43 & 0.95 \\
$\mathrm{C}_{\mathrm{w}-4 \mathrm{~h}}(\mathrm{ng} / \mathrm{mL})$ & 0.08 & 4.66 & 0.20 & 0.12 & 0.10 & 0.10 & 0.75 & 0.63 \\
\hline
\end{tabular}

$\mathrm{D}_{\mathrm{sm}}$, subliminal dose; Pp/Ps, the ratio of the pulmonary arterial pressure to the systemic pressure; $\mathrm{D}_{\mathrm{s}}$, stable dose; $\mathrm{D}_{\mathrm{m}}$, max dosage; C $\mathrm{Dm}_{\mathrm{m}}$ concentrations at max dosage of treprostinil, which was $80 \mathrm{ng} / \mathrm{kg} / \mathrm{min}$; Cs, concentrations at a stable dosage of treprostinil; $\mathrm{C}_{\mathrm{w}-2 \mathrm{~h}} \& \mathrm{C}_{\mathrm{w}-4 \mathrm{~h}}$, concentrations 2 and 4 hours after withdrawal of treprostinil. 

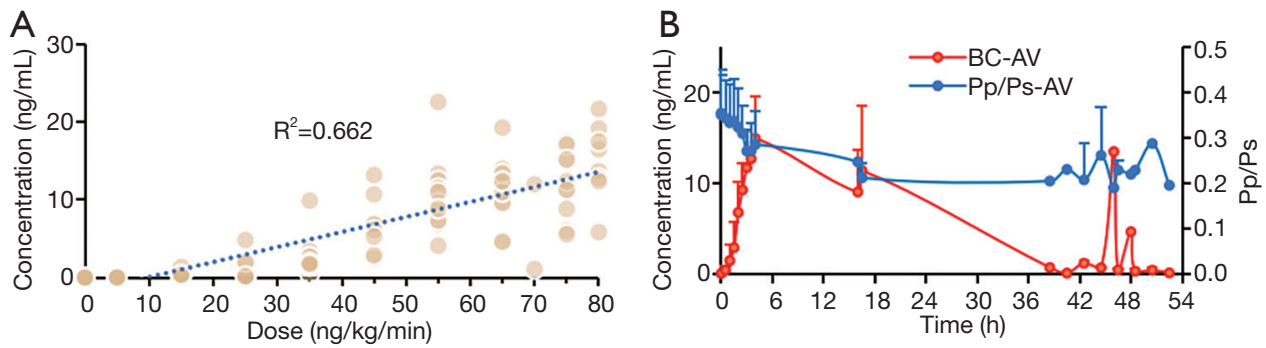

Figure 3 Scatter plot of dose and concentration. (A) The linear relationship between concentration and dose is as follow: $\mathrm{Y}=1.76+0.19 \times \mathrm{X}$. (X: dose; Y: concentration), $\mathrm{R}^{2}=0.662$. (B) The relationship between blood concentration and $\mathrm{Pp} / \mathrm{Ps}$. Pp/Ps, the ratio of the pulmonary arterial pressure to the systemic pressure.

Table 4 Significant factors associated with blood concentration identified by multiple linear regression model

\begin{tabular}{lcccccc}
\hline & \multirow{2}{*}{$\beta$} & $\mathrm{t}$ & $\mathrm{P}$ & \multicolumn{2}{c}{$95 \% \mathrm{Cl}$} \\
\cline { 5 - 6 } & & & & \multicolumn{2}{c}{ Lower limit } & Upper limit \\
\hline Constant & -15.525 & -7.354 & $<0.001$ & -19.746 & -11.303 \\
$\begin{array}{l}\text { Dose } \\
\text { (ng/kg/min) }\end{array}$ & 0.235 & 15.332 & $<0.001$ & 0.205 & 0.266 \\
Height $(\mathrm{cm})$ & 0.113 & 5.864 & $<0.001$ & 0.075 & 0.152 \\
\hline
\end{tabular}

Concentration $=-15.525+0.235 \times$ dose $(\mathrm{ng} / \mathrm{kg} / \mathrm{min})+0.113 \times$ height $(\mathrm{cm}), \mathrm{F}=134.73, \mathrm{P}<0.001, \mathrm{R}^{2}=0.809$, Adjusted $\mathrm{R}^{2}=0.802$.

Table 5 The therapeutic effect of treprostinil

\begin{tabular}{lcc}
\hline Index & Before treatment & After treatment \\
\hline mPAP $(\mathrm{mmHg})$ & $18.63 \pm 3.66$ & $15.38 \pm 3.5^{\star}$ \\
$\mathrm{Pp} / \mathrm{Ps}$ & $0.35 \pm 0.11$ & $0.22 \pm 0.06^{\star \star}$ \\
$\mathrm{P} / \mathrm{F}(\mathrm{mmHg})$ & $102.57 \pm 34.31$ & $162.29 \pm 56.16^{\star}$ \\
IS (score) & $9.56 \pm 4.66$ & $14.56 \pm 9.92$ \\
\hline
\end{tabular}

IS = dopamine $(\mu \mathrm{g} / \mathrm{kg} / \mathrm{min})+$ dobutamine $(\mu \mathrm{g} / \mathrm{kg} / \mathrm{min})+10 \times$ milrinone $(\mu \mathrm{g} / \mathrm{kg} / \mathrm{min})+100 \times$ adrenergic $(\mu \mathrm{g} / \mathrm{kg} / \mathrm{min})+100$ $\times$ noradrenaline $(\mu \mathrm{g} / \mathrm{kg} / \mathrm{min})$. Treprostinil treatment $v s$. before treatment, ${ }^{\star} \mathrm{P}<0.05,{ }^{\star \star} \mathrm{P}<0.01$. mPAP, mean pulmonary artery pressure; $\mathrm{Pp} / \mathrm{Ps}$, the ratio of the pulmonary arterial pressure to the systemic pressure; P/F, oxygenation index; IS, inotropic drug score.

route might be a better choice for children with PAH (17).

Several studies have reported the therapeutic effect of TRE in pediatric patients with $\mathrm{PAH}$, but documented results of TRE in pediatric patients with FSV-PAH are lacking. The goal dose of TRE was approximately $20 \mathrm{ng} / \mathrm{kg} / \mathrm{min}$ in many studies $(18,21)$. De Bie et al. reported TRE concentrations during clinical treatment in four neonates on extracorporeal membrane oxygenation support (18). The starting dose of TRE was $4 \mathrm{ng} / \mathrm{kg} / \mathrm{min}$ and was gradually increased by $4 \mathrm{ng} / \mathrm{kg} / \mathrm{min}$ every 8 hours aiming for a dose of $20 \mathrm{ng} / \mathrm{kg} / \mathrm{min}$ (18). Finally, TRE doses ranging from 20 to $58 \mathrm{ng} / \mathrm{kg} / \mathrm{min}$ reached concentrations of $0.99-4.39 \mathrm{ng} / \mathrm{mL}$ in these neonates with $\mathrm{PAH}$ and resulted in clinical improvement (18). Levy et al. found that the average stable dose of SC TRE in children with severe PAH was $55 \mathrm{ng} / \mathrm{kg} / \mathrm{min}$ with a range of $15-350 \mathrm{ng} / \mathrm{kg} / \mathrm{min}$ (17). A pharmacokinetic study of oral TRE in pediatric patients with PAH indicated that TRE concentration had a linear relationship to oral TRE dose, and pediatric patients might require a higher oral TRE dose than adults (14). This phenomenon was also observed in pediatric patients who received steady-state $I V$ and SC TRE (13). In this study, we chose $5 \mathrm{ng} / \mathrm{kg} / \mathrm{min}$ as an initial rate with an increasing rate of $10 \mathrm{ng} / \mathrm{kg} / \mathrm{min}$ every $30 \mathrm{~min}$ up to the aiming dose of $80 \mathrm{ng} / \mathrm{kg} / \mathrm{min}$ to explore the blood concentration of $\mathrm{IV}$ TRE in SV CHD patients undergoing Fontan surgery. The relationship between the concentration and the dose was approximately linear, and the corresponding concentration was $0.05-21.7 \mathrm{ng} / \mathrm{mL}$. The drug concentration reached a relatively stable level at approximately $16 \mathrm{~h}$. Moreover, our results indicated that the subliminal dose range for our patients was $25-75 \mathrm{ng} / \mathrm{kg} / \mathrm{min}$, and the final stable dose range was $55-75 \mathrm{ng} / \mathrm{kg} / \mathrm{min}$ with an average stable dose of $65.00 \pm 7.07 \mathrm{ng} / \mathrm{kg} / \mathrm{min}$. These doses were higher than the doses determined in previous investigations (14). Our results suggested that pediatric patients with FSV-PAH are more likely to need a higher therapeutic dose of TRE than general PAH patients. To further explore the influencing factors of TRE blood concentration, we used a multiple linear regression analysis with age, height, body surface area, peritoneal dialysis data, hepatic, and renal functions as the independent variables. We found that TRE blood 
concentrations were associated with two factors: dose and height. Since the therapeutic dose of TRE was determined by weight in this study, these results from the multiple linear regression model suggest that the use of body surface area to determine the therapeutic dose might be a better choice for pediatric patients with $\mathrm{PAH}$.

The efficacy and safety of TRE were also investigated in this study. A single center retrospective cohort study by Handler et al. reported that 17 pediatric patients with SV physiology who received SC TRE demonstrated clinical benefits, with improvements in oxygen saturation, exercise tolerance, and PVR index (19). TRE therapy in children with $\mathrm{PAH}$ also showed an improved pulmonaryto-systemic vascular resistance ratio (Rp/Rs) (22), and TRE has been shown to lower the mPAP in patients with PAH (23). Furthermore, add-on therapy with SC TRE had a rescue value in children with refractory PAH (24), and TRE therapy improved symptoms and hemodynamics in pediatric patients with mild $\mathrm{PAH}$ awaiting heart transplantation (21). However, the efficacy and safety data of IV TRE in pediatric populations with FSV-PAH are limited. In this study, we found that IV TRE improved mPAP, $\mathrm{Pp} / \mathrm{Ps}$, and $\mathrm{PaO}_{2} / \mathrm{FiO}_{2}$ in children with FSV-PAH. Besides vasodilation, TRE can also inhibit platelet activation (25), and thrombocytopenia is a common side effect during TRE treatment (26). In this study, we also observed a decreased platelet count in all patients after TRE treatment. However, the platelet count recovered before discharge in the absence of a platelet transfusion. Therefore, the decrease in platelets was considered to be surgery related. Although improvements in tissue oxygenation, enhanced cardiac function, and hemodynamic stability were established in our study, further large-sample research is needed to confirm our findings.

\section{Limitations}

Certain limitations of this study should be acknowledged. Firstly, because it was hard for patients to accept sparse PK research, the sample size was small, which may have introduced bias. However, in our follow-up study, we're still collecting relevant samples. Therefore, we will continue to report related studies in the future. Secondly, we established that TRE significantly improved mPAP, $\mathrm{Pp} / \mathrm{Ps}$, and $\mathrm{PaO}_{2} /$ $\mathrm{FiO}_{2}$, but further studies are needed to confirm whether it can improve the short-term prognosis of Fontan children. Thirdly, PVRI was not evaluated in our investigation.

\section{Conclusions}

In this study, we investigated the PK of IV TRE in children with FSV-PAH. TRE blood concentrations were associated with dose and patient height. A linear relationship was found between the blood concentration of TRE and its dose. The use of body surface area to determine the therapeutic dose of TRE might be a better choice. IV TRE resulted in the improvement of mPAP, $\mathrm{Pp} / \mathrm{Ps}$, and $\mathrm{PaO}_{2} /$ $\mathrm{FiO}_{2}$ in children with FSV-PAH.

\section{Acknowledgments}

The authors express gratitude for the support of the Pharmaceutical Molecular Laboratory of Fudan University. Funding: This article was supported by the National Nature Science Foundation of China (Grant No. 81771934) and the Shanghai "Rising Stars of Medical Talent" Youth Development Program Youth Medical Talents-Clinical Pharmacist Program (SHWRS [2020]_087).

\section{Footnote}

Reporting Checklist: The authors have completed the CONSORT reporting checklist. Available at https://dx.doi. org/10.21037/atm-21-3188

Trial Protocol: Available at https://dx.doi.org/10.21037/atm21-3188

Data Sharing Statement: Available at https://dx.doi. org/10.21037/atm-21-3188

Conflicts of Interest: All authors have completed the ICMJE uniform disclosure form (available at https://dx.doi. org/10.21037/atm-21-3188). The authors have no conflicts of interest to declare.

Ethical Statement: The authors are accountable for all aspects of the work in ensuring that questions related to the accuracy or integrity of any part of the work are appropriately investigated and resolved. This study was approved by the Ethics Committee of Shanghai Children's Medical Center affiliated with Shanghai Jiao Tong University School of Medicine (approval number: SCMCIRB-K201538). The study protocol was conducted in accordance with good clinical practice and the Helsinki Declaration (as revised in 2013). Oral and written 
explanations of the benefits and risks of participating in this study were communicated to the participants' legal guardians. Written informed consent from the subjects' legal guardians was obtained before the start of the study.

Open Access Statement: This is an Open Access article distributed in accordance with the Creative Commons Attribution-NonCommercial-NoDerivs 4.0 International License (CC BY-NC-ND 4.0), which permits the noncommercial replication and distribution of the article with the strict proviso that no changes or edits are made and the original work is properly cited (including links to both the formal publication through the relevant DOI and the license). See: https://creativecommons.org/licenses/by-nc-nd/4.0/.

\section{References}

1. Triedman JK, Newburger JW. Trends in Congenital Heart Disease: The Next Decade. Circulation 2016;133:2716-33.

2. Baumgartner H, De Backer J, Babu-Narayan SV, et al. 2020 ESC Guidelines for the management of adult congenital heart disease. Eur Heart J 2021;42:563-645.

3. Schidlow DN, Gauvreau K, Cherian KM, et al. SingleVentricle Palliation in Low- and Middle-Income Countries. J Am Coll Cardiol 2019;74:928-31.

4. Hauck A, Porta N, Lestrud S, et al. The Pulmonary Circulation in the Single Ventricle Patient. Children (Basel) 2017;4:71.

5. d'Udekem Y, Iyengar AJ, Galati JC, et al. Redefining expectations of long-term survival after the Fontan procedure: twenty-five years of follow-up from the entire population of Australia and New Zealand. Circulation 2014;130:S32-8.

6. Rodriguez FH, Book WM. Management of the adult Fontan patient. Heart 2020;106:105-10.

7. Malhotra SP, Ivy DD, Mitchell MB, et al. Performance of cavopulmonary palliation at elevated altitude: midterm outcomes and risk factors for failure. Circulation 2008;118:S177-81.

8. Jozefkowicz M, Haag DF, Mazzucchelli MT, et al. Neonates Effects and Tolerability of Treprostinil in Hypertension with Persistent Pulmonary. Am J Perinatol 2020;37:939-46.

9. Hansmann G, Koestenberger M, Alastalo TP, et al. 2019 updated consensus statement on the diagnosis and treatment of pediatric pulmonary hypertension: The European Pediatric Pulmonary Vascular Disease Network (EPPVDN), endorsed by AEPC, ESPR and ISHLT. J
Heart Lung Transplant 2019;38:879-901.

10. Cai J, Su Z, Shi Z, et al. Nitric oxide in conjunction with milrinone better stabilized pulmonary hemodynamics after Fontan procedure. Artif Organs 2008;32:864-9.

11. Brida M, Diller GP, Nashat H, et al. Pharmacological therapy in adult congenital heart disease: growing need, yet limited evidence. Eur Heart J 2019;40:1049-56.

12. McSwain CS, Benza R, Shapiro S, et al. Dose proportionality of treprostinil sodium administered by continuous subcutaneous and intravenous infusion. J Clin Pharmacol 2008;48:19-25.

13. Hall K, Ogawa M, Sakarovitch C, et al. Subcutaneous and Intravenous Treprostinil Pharmacokinetics in Children With Pulmonary Vascular Disease. J Cardiovasc Pharmacol 2019;73:383-93.

14. Hopper RK, Ivy DD, Yung D, et al. Pharmacokinetics of Oral Treprostinil in Children With Pulmonary Arterial Hypertension. J Cardiovasc Pharmacol 2020;76:94-100.

15. Lawrence KM, Hedrick HL, Monk HM, et al. Treprostinil Improves Persistent Pulmonary Hypertension Associated with Congenital Diaphragmatic Hernia. J Pediatr 2018;200:44-9.

16. Gavotto A, Thomas F, Werner O, et al. Use of Treprostinil in Pediatric Pulmonary Hypertension: Case Reports and Review of the Literature. J Cardiovasc Pharmacol 2020;76:23-31.

17. François T, Emeriaud G, Karam O, et al. Transfusion in children with acute respiratory distress syndrome. Ann Transl Med 2019;7:511.

18. De Bie FR, Allegaert K, Hedrick HL, et al. Treprostinil Attains Clinically Therapeutic Concentrations in Neonates with Pulmonary Hypertension on Extracorporeal Membrane Oxygenation Support. Pharmacotherapy 2020;40:1054-60.

19. Handler SS, Ogawa MT, Hopper RK, et al. Subcutaneous treprostinil in pediatric patients with failing singleventricle physiology. J Heart Lung Transplant 2017. [Epub ahead of print]. doi: 10.1016/j.healun.2017.09.008.

20. Jackson EO, Brown A, McSweeney J, et al. Pediatric subcutaneous treprostinil site maintenance and pain control strategies from the Pediatric Pulmonary Hypertension Network. Pulm Circ 2021;11:2045894021994450.

21. Hollander SA, Ogawa MT, Hopper RK, et al. Treprostinil improves hemodynamics and symptoms in children with mild pulmonary hypertension awaiting heart transplantation. Pediatr Transplant 2020;24:e13742.

22. Siehr SL, Ivy DD, Miller-Reed K, et al. Children with pulmonary arterial hypertension and prostanoid therapy: 
long-term hemodynamics. J Heart Lung Transplant 2013;32:546-52.

23. Huang ST, Xu N, Sun KP, et al. Effect of Treprostinil on the Early Postoperative Prognosis of Patients with Severe Left Heart Valvular Disease Combined with Severe Pulmonary Hypertension. Ann Thorac Cardiovasc Surg 2021;27:18-24.

24. Levy M, Celermajer DS, Bourges-Petit E, et al. Add-on therapy with subcutaneous treprostinil for refractory pediatric pulmonary hypertension. J Pediatr 2011;158:584-8.

Cite this article as: Chen X, Cai XM, Zhang MJ, Xu JH, Li H, $\mathrm{Xu}$ ZM. Pharmacokinetics of treprostinil in children with functional single-ventricle pulmonary arterial hypertension: a randomized controlled trial. Ann Transl Med 2021;9(14):1163. doi: $10.21037 /$ atm-21-3188
25. Bacha NC, Levy M, Guerin CL, et al. Treprostinil treatment decreases circulating platelet microvesicles and their procoagulant activity in pediatric pulmonary hypertension. Pediatr Pulmonol 2019;54:66-72.

26. Ablonczy L, Tordas D, Kis E, et al. Use of subcutaneous treprostinil in pediatric pulmonary arterial hypertensionBridge-to-transplant or long-term treatment? Pediatr Transplant 2018. doi: 10.1111/petr.13106.

(English Language Editor: D. Fitzgerald) 